\title{
Improving Entrepreneurial Ability through Knowledge-Sharing Intention in Millennial Generation
}

\author{
Anissa Lestari Kadiyono*, Rizal Judawinata \\ Fakultas Psikologi \\ Universitas Padjadjaran \\ Bandung, Indonesia \\ *anissa.lestari@unpad.ac.id, rizal12003@unpad.ac.id
}

\begin{abstract}
Knowledge-sharing is a way to improve entrepreneurial readiness in millennial generation. One key feature of the industrial revolution 4.0 is the need for capability in data literacy, technological literacy, and human literacy. Building community as a place to share can improve readiness of millennial generation to develop entrepreneurship. The purpose of this study was to determine knowledge-sharing intention in millennial generation as member of a community. This study examined determinants of intention and the underlying beliefs to improve entrepreneurial readiness. Participants in this study were 61 members of an entrepreneurship learning community. This study used descriptive - quantitative approach and used an instrument based on Planned Behaviour Theory. The result showed that millennial generation in entrepreneurship learning community had a strong intention to share knowledge in the time of being a part of entrepreneurial community. Determinant that significantly influenced was Attitude toward Behaviour. This determinant was based on salient beliefs that knowledge-sharing will open up business opportunities and improve knowledge about business.
\end{abstract}

Keywords-knowledge-sharing intention, planned behavior, entrepreneurship, millennial generation

\section{INTRODUCTION}

The number of people with productive age in Indonesia (15-60 years) reaches 166.06 million in statistics. This indicates that more than $50 \%$ of population in Indonesia is of productive age. It is the age in which people actively work and do productive activities. The dominant range of age out of the total population with productive age is 15 to 39 years, totalling 84.75 million out of 261 million of total population in Indonesia. Hence, approximately $32 \%$ of population in Indonesia is currently of productive age that belong to generation $\mathrm{Y}$, which is commonly referred to as millennials [1].

Millennials or generation $\mathrm{Y}$ is a generation born between 1980 and 2000 [2]. This generation was born at the same time as the development of information technology which was increasingly advanced yet cheaper and more affordable for everyone. Generation Y have several distinctive characteristics such as being optimistic, confident, narcissistic, demanding feedback, and easily bored [3]. A research revealed that generation $\mathrm{Y}$ are eager to work because they place interest and enjoyment of their work [4]. In fact, generation $Y$ are considered to have a tendency to switch jobs quickly [5], including running business.

Based on Harvard Business Review 2006 [6], generation Y have a low level of work engagement. One possible reason for their low level of work engagement is that they were born with the availability of broad knowledge and many choices, including employment and entrepreneurship. Improving entrepreneurial skills in millennials can be done by building communities in which knowledge-sharing is implemented.

Knowledge-sharing is a process of disseminating and exchanging information, ideas, experiences, knowledge, through communication and social interaction undertaken by individuals with other individuals, individuals with groups, or between groups inside and outside organization aiming to create new knowledge [7]. According to Srivastas, Bartol, and Lock [8], knowledge-sharing is important because it allows the codification and repository of existing knowledge, therefore it can be developed. Development of this knowledge is a competitive advantage of an organization. Anumu [8] stated that properly managed and utilized knowledge will increase productivity, enterprise development, corporate growth, and sustainable profit. Hossain [8] stated that the knowledge flow can be utilized by organizations to accelerate internal innovation and expand the markets for external use of innovation.

Entrepreneurship learning community can be built to collaborate and implement knowledge-sharing in order to help grow them together. One of such communities in West Java Province, Indonesia, has special activities for its members in term of sharing their knowledge. The activity is called Learning Day. During this activity, each present member shares about their business problems or innovations, followed 
by a discussion with other members who run different businesses. There is a keynote speaker in this activity, however everyone is allowed to be involved in the discussion session. They further became participants in this study.

In knowledge-sharing process, knowledge-sharing behaviour is important for the process to run optimally. According to Ajzen and Fishbein [9], behaviour can occur when there is an intention to do so. Forming intention can occur when three components are fulfilled, namely attitudes toward the behaviour, subjective norms, and perceived control of the behaviour. Attitude is a disposition to respond a certain level of pleasure or displeasure to a psychological object [10]. The more positive a person's attitude toward the knowledgesharing behaviour, the higher the role of attitude in supporting knowledge-sharing behaviour. The second is subjective norm, which is a perceived social pressure to perform (or not perform) a behaviour [11]. This component explains that the more important people around them to support or engage in the knowledge-sharing behaviour, the stronger the knowledgesharing intention will be. The third is perceived behaviour control which means a belief about one's ability to perform a behaviour, that they have control over their performance [11]. This component explains that the more confident people are of their ability to share knowledge, the higher their intention to share knowledge will be. In order to create strong intention, all these components are not necessarily high, however these components can complement each other [12].

The three components of intention are based on something more fundamental, namely beliefs [13]. Beliefs represent information of an object - that the object is related to a particular attribute. For instance, believing that knowledgesharing behaviour is useful. The object (knowledge-sharing behaviour) is associated with certain attributes (beneficial, not harmful). Beliefs have three types, namely behavioural, normative, and control [13]. Behavioural beliefs are a belief in the relationship between behaviour and the consequences of the behaviour. Normative beliefs are a belief that certain people or groups agree or disregard behaviour, that people and groups perform or not perform the behaviour. Control beliefs is a belief in the availability of factors that can facilitate or inhibit behavioural performance [13].

In order to determine intention using the concept of beliefs, we cannot separate one belief with another. Total of the three beliefs form dimensions of one's intention that will finally be able to predict if a person will perform a behaviour. Therefore, researchers are interested to examine further how intention of knowledge-sharing behaviour can improve entrepreneurial ability in millennial generation.

\section{METHODS}

This study was a quantitative research using survey method. The population was member of The Local Enablers located in Jatinangor-Sumedang, Indonesia, which was millennials. Using simple random technique, there were 61 participants participated in this study.
Researchers used two measurement techniques, namely direct measurement and indirect measurement. Direct measurement was a way to measure intention by asking participants directly about their attitudes, social pressure they experienced, and factors that facilitated or inhibited knowledge-sharing behaviour. A total of 48 items were developed in this measurement, based on explanation of dimensions and their divisions. This measurement technique generalized behaviour in all research contexts.

Indirect measurement was an intention measurement technique based on beliefs that complemented each of its dimension. In attitude dimension, there was behavioural beliefs and its complement, namely outcome evaluation. In subjective norm, there was normative beliefs and its complement, namely motivation to comply. In perceived control, there was control beliefs and its complement, namely perceived power.

\section{RESULTS AND DISCUSSION}

Based on data obtained from 61 members of an entrepreneurial community, the category of their knowledgesharing intention is shown in Table 1.

TABLE I. INTENTION OF KNOWLEDGE-SHARING BEHAVIOR

\begin{tabular}{|l|l|l|}
\hline $\begin{array}{c}\text { Category of } \\
\text { Intention }\end{array}$ & $\begin{array}{c}\text { Number of } \\
\text { Participants }\end{array}$ & Percentage \\
\hline Strong & 53 & $86,9 \%$ \\
\hline Weak & 8 & $13,1 \%$ \\
\hline
\end{tabular}

Intention category have two category of intention, which is people with strong intention and people with weak intention [14]. Researchers then measured the intention based on items from questionnaire that directly measured the intention. Based on Table 1 , it can be seen that 8 people $(13.1 \%$ ) have weak intention to share knowledge and the other 53 people $(86.9 \%)$ have strong intention to share knowledge in the time of being a part of the entrepreneurial community.

The majority of community members have a strong intention to share their knowledge. Based on Table 1, more than half of the participants $(86.9 \%)$ have a strong intention to share knowledge. Strong intention means they feel the possibility of sharing knowledge is moderately high. This might manifest in the form of planning, wanting to, and expecting to share knowledge during Learning Day.

Each determinant contributes to different levels of intention of knowledge-sharing in the time of being a part of the community. The analysis used in this study was to determine the influence of attitude toward behaviour, subjective norm, and perceived behaviour control variables on member's intention to share knowledge in the time of being a part of the community. The result of regression analysis is shown in Table 2. 
TABLE II. REGRESSION ANALYSIS OF DETERMINANTS

\begin{tabular}{|l|l|l|l|}
\hline \multicolumn{1}{|c|}{ Model } & \multicolumn{1}{|c|}{$\begin{array}{c}\text { Unstandardized } \\
\text { Coefficient }\end{array}$} & T & Sig. \\
\cline { 2 - 3 } & \multicolumn{1}{|c|}{$\boldsymbol{B}$} & & \\
\hline Constant & 1.571 & 1.809 & .076 \\
\hline $\begin{array}{l}\text { Attitude } \\
\begin{array}{l}\text { Toward } \\
\text { Behavior }\end{array}\end{array}$ & .265 & 6.262 & .000 \\
\hline $\begin{array}{l}\text { Subjective } \\
\text { norm }\end{array}$ & .052 & .607 & .546 \\
\hline $\begin{array}{l}\text { Perceived } \\
\text { behavioral } \\
\text { control }\end{array}$ & .144 & 1.152 & .254 \\
\hline
\end{tabular}

Based on Table 2, the contribution value of each determinant varies. All determinants do not necessarily contribute significantly in order to form intention of knowledge-sharing [15]. Based on Table 2, the determinant that contributes significantly to knowledge-sharing behaviour in the community is attitude toward behaviour. Contributions of subjective norm and perceived behaviour control to knowledge-sharing intention are not significant. This is in accordance with a meta-analysis study by Fishbein and Ajzen in which attitudes have the highest correlation with intention [11]. The significant contribution means the determinant has an influence on forming intention to share knowledge. Therefore, the members' positive or negative evaluations of knowledgesharing behaviour are more important in determining the likelihood to share their knowledge, compared to the social pressure they experience or the factors they believe to inhibit or facilitate knowledge-sharing in the time of being a part of the community [16].

The analysis used in this study was to determine the influence of attitude toward behaviour, subjective norm, and perceived behaviour control variables on members' intentions to share knowledge in the community. The result of regression analysis is shown in Table 3.

TABLE III. REGRESSION ANALYSIS OF BEHAVIORAL BELIEFS

\begin{tabular}{|l|l|l|l|}
\hline \multirow{2}{*}{ Model } & \multicolumn{1}{|c|}{$\begin{array}{c}\text { Unstandardized } \\
\text { Coefficient }\end{array}$} & \multirow{2}{*}{ T } & \multirow{2}{*}{ Sig. } \\
\cline { 2 - 3 } & \multicolumn{1}{|c|}{ B } & & \\
\hline Constant & 19.029 & 11.308 & .000 \\
\hline Belief 1 & .561 & 3.285 & $\mathbf{. 0 0 2}$ \\
\hline Belief 2 & -.131 & -.648 & .520 \\
\hline Belief 3 & .647 & 4.519 & $\mathbf{. 0 0 0}$ \\
\hline
\end{tabular}

Based on Table 3, belief 1 and belief 3 have t-values that are greater than the critical value. This indicates beliefs that knowledge-sharing in the community can improve knowledge about business, and beliefs that knowledge-sharing in the community can open up business opportunities, contribute significantly.

In this study, there are two main behavioural beliefs that form the attitude of knowledge-sharing behaviour in the time of being a part of the community. First, beliefs that knowledgesharing in the community will open up business opportunities.
Second, beliefs that knowledge-sharing in the community will improve business knowledge. This means that the positive or negative attitudes of members toward knowledge-sharing depend on their perceptions of the extent to which their business knowledge has improved and on the extent to which business opportunities are open to them. The more the members feel their business knowledge has improved and the more open the business opportunity to them, the more positive their attitude will be and the stronger their intention to share. The open business opportunities and improved business knowledge will be supported by the diversity of existing businesses in the community. The diversity of business means there is a wide variety of knowledge in the community. By carrying out regular knowledge-sharing activities, the implicit knowledge will then be explicit. This explicit knowledge (might be information about new business venues or specific skill workshops) will be easier to share. Therefore, it will improve knowledge and support business innovation.

\section{CONCLUSION}

In conclusion, knowledge-sharing intention of community members in the time of being a part of the community include:

Attitude toward behaviour is a determinant that contributes significantly to knowledge-sharing in the community. Subjective norm and perceived behaviour control are determinants that contribute insignificantly to form intention. The majority of members have a strong intention to share their knowledge which indicates their moderately high tendencies to engage in knowledge-sharing behaviour. Beliefs underlying the intention of knowledge-sharing is the beliefs that knowledgesharing will open up business opportunities and improve business knowledge. These are behavioural beliefs that will influence the intention through attitude toward behaviour.

\section{REFERENCES}

[1] Statistik Indonesia, 2019.

[2] J. Meier and M. Crocker, "Generation Y in the Workforce: Managerial Challenges," J. Hum. Resour. Adult Learn., vol. 6, no. 1, pp. 68-78 2010.

[3] S. Kar, "Managing generation y employees-Hr challenges and opportunities," Sambrham Academy and Management Studies, 2018.

[4] S. Hays, S. Page and D. Buhalis, "Social media as a destination marketing tool: An exploratory study of the use of social media among National Tourism Organisations," Curr. Issues Tour., vol. 66, no. 3, pp. 37-39, 2012.

[5] A.N. Asih and Z. Zamralita, "Gambaran Turnover Intention Pada Karyawan Generasi Y Di Pt. Xyz (It Solution Company)," J. Muara Ilmu Sos. Humaniora, dan Seni, vol. 1, no. 2, pp. 118, 2018.

[6] D.A. Garvin, A.C. Edmondson, and F. Gino, "Is yours a learning organization?," Harv. Bus. Rev., vol. 86, no. 3, 2008

[7] N. Indarti and D. Dyahjatmayanti, Manajemen Pengetahuan: Teori dan Praktik. Yogyakarta: Gadjah Mada University Press, 2014.

[8] G. Soerjoatmodjo, “Soerjoatmodjo, 2015," Widyakala J. Pembang. Jaya Univ., vol. 2, pp. 24-36, 2015

[9] R.J. Vallerand, P. Deshaies, J.P. Cuerrier, L.G. Pelletier and C Mongeau, "Ajzen and Fishbein's Theory of Reasoned Action as Applied to Moral Behavior: A Confirmatory Analysis," J. Pers. Soc. Psychol., vol. 62 , no. 1 , pp. $98-109,1992$ 
[10] M. Fishbein and I. Ajzen, "Predicting and changing behavior: The reasoned action approach," Predict. Chang. Behav. Reason. Action Approach, no. January 2007, pp. 1-518, 2011.

[11] I. Ajzen, "The theory of planned behaviour is alive and well, and not ready to retire: a commentary on Sniehotta, Presseau, and AraújoSoares," Health Psychol. Rev., vol. 9, no. 2, pp. 131-137, 2015.

[12] J.S. Barber, "The Theory of Planned Behaviour: considering drives, proximity and dynamics. Vienna yearbook of population research/Vienna Institute of Demography," Austrian Academy of Sciences, vol. 9, no. 31, 2011.
[13] I. Ajzen, "The theory of planned behaviour: Reactions and reflections," Psychol. Heal., vol. 26, no. 9, pp. 1113-1127, 2011.

[14] H.H. Nguyen and T.D. Nguyen, "Satisfaction, Value and Intention to Return in Hotels,” Int. J. Contemp. Hosp. Manag., pp. 1-22, 2013.

[15] L. Chen and X. Yang, "Using EPPM to Evaluate the Effectiveness of Fear Appeal Messages Across Different Media Outlets to Increase the Intention of Breast Self-Examination Among Chinese Women," Health Commun., vol. 34, no. 11, pp. 1369-1376, 2019.

[16] A. Madahi and I. Sukati, "The Effect of External Factors on Purchase Intention amongst Young Generation in Malaysia," Int. Bus. Res., vol. 5, no. 8, pp. 153-159, 2012. 